Metodički obzori 8(2013)1

UDK: 821.131.1(497.5)

Review article

Primljeno: 17. 10. 2012.

\title{
INTERCULTURAL LITERATURE IN ITALIAN LANGUAGE IN THE MIDST OF NATIONAL LITERATURES
}

\author{
Dario Saftich, Edit Rijeka, Croatia \\ dario.saftich@ri.t-com.hr
}

\begin{abstract}
:
When speaking about the literature of Croatia's Italian minority, its beginnings can be traced to 1945 . Newly formed borders, the immigration influx into Italy and overseas regions, the fleeing of left-wing oriented citizens, especially intellectuals, out of Italy, a new socio-political order all lay the groundwork for the creation of a specific, albeit very developed minority's literature. However, it should be taken into account that whilst the literature of the minority was developing in Croatia, the diaspora's literature also began to appear. In this essay, we will present a summarized depiction of these two literatures as well as their mutual relationship from both an Italian and Croatian perspective. We have deliberately avoided using the term «literature of the Italian minority», as it is important to note that use of a certain language doesn't necessarily imply national affiliation with a certain national group and there generally exist differing opinions, especially in Rijeka, as to the criteria used to define affiliation as such.
\end{abstract}

Keywords: literature, Italian minority, diaspora, criteria, national affiliation, language

\section{Introduction}

When speaking about the literature of Croatia's Italian minority, its beginnings can be traced to 1945. Before that, from 1919 to 1945 , authors who wrote in Italian in Istria, Rijeka and Zadar were considered part of Italian national literature, albeit with certain attributed specificities. If we go back even further in time, only taking into the account the Austro-Hungarian Empire, the situation was even more complex: the «capital» of the North Adriatic was Trieste, a metropolis of sorts toward which a significant part of Istria, as well as a thick region encompassed by the East Adriatic coast, gravitated towards in both an economic and cultural sense. Italian language literature in Trieste developed impressively and overshadowed all other neighboring regions' literary production, thanks to the Central European spirit of the Austro-Hungarian Monarchy and the presence of a wealthy bourgeoisie. Certain authors were of Istrian extraction and this factor came to represent, in a thematic sense, a tie of sorts. Naturally, Croatian and Slovenian literature was also very expressed in this macroregion, in addition to Italian. The peoples' national awakening in the midst of Austro-Hungary offered favorable circumstances for the development of historiographic and scientific-linguistic 
productions, which then acquired literary-fictional markers in certain situations, as they themselves often served to preserve national identity.

Works written in the Italian language that came to be in Trieste during the Austro-Hungarian period, as well as their authors, are now considered part of Italian literature, although the geographic, political and ethnic specificities of their creation are noted by the Italian. The famed Triestini poet of a Jewish background, Umberto Saba once declared that writing in Italian in Trieste before 1919 was the equivalent of writing in Italy before 1860. Naturally, Saba was referring to Italy before its unification, when the Apennine Peninsula was divided into numerous smaller states or regions within Austro-Hungary. However, the situation is not as simple as Umberto Saba made it out to be. Ethnic, linguistic, political and geographic specificities left a profound mark on the works of most Triestini authors, not to mention those born farther South upon the Adriatic's Eastern coast. The Italian language itself, whilst submerged within a multilingual (and multidialectic) environment, was inevitably influenced by the specificities of its position.

All the aforementioned specificities were multiplied significantly in Istria and Rijeka after 1945. Newly formed borders, the immigration influx into Italy and overseas regions, the fleeing of left-wing oriented citizens, especially intellectuals, out of Italy, a new socio-political order all lay the groundwork for the creation of a specific, albeit very developed minority's literature. Even today, it is unclear what specifically what falls under the notion of the Italian minority's literature within Croatia. In its anthologies and presentations, the minority usually includes those authors who were born and remained active in the Istria region and Rijeka after 1945, as well as the intellectuals who arrived in Italy after World War II (or were already battling for Partisan forces, i.e. The National Liberation Army and remained in post-war Croatia), those who became rooted within this new environment and significantly contributed to the development and affirmation of the minority's culture and literature.

However, it should be taken into account that whilst the literature of the minority was developing in Croatia, the diaspora's literature also began to appear. When speaking of the latter, we most often speak of the authors whose works are tied to the regions of Istria, Rijeka and Dalmatia, and which deal with the theme of Italian and Croatian cultural and linguistic acquaintance.

In this essay, we will present a summarized depiction of these two literatures as well as their mutual relationship from both an Italian and Croatian perspective, as well as parsing the main characteristics of Italian language literature in Istria and Rijeka. We have deliberately avoided using the term «literature of the Italian minority», as it is important to note that use of a certain language doesn't necessarily imply national affiliation with a certain national group and there generally exist differing opinions, especially in Rijeka, as to the criteria used to define affiliation as such. 


\section{Literature of the Italian minority and national literatures}

In his Introduction to Comparative Literature, Miroslav Beker addresses the problem of determining to which group a certain literature belongs: The term «national literature» encompasses what we consider to be, naturally, literature written in the language of its people (Croatian literature in Croatia, German literature in Germany, etc.). However, a dilemma the presents itself, one of which Weisstein speaks of, and that is whether a political-historical or linguistic dimension will be taken into account when determining a certain literature's classification. (Beker, 1995, 23) Beker notes that it is not always simple to determine to which classification a certain literature belongs: Let us imagine an Italian from Istria who writes in Italian about the life of an Italian within Istria, as well as his relationship with the Croatian population. Although this (rhetorical) work is written in Italian, can we without hesitation consider it Italian literature? Or the work of a Burgenlandish Croat about our people's way of life in Burgenland, their existence within Austria, etc., does such a work belong exclusively to Croatian literature? In such situations, I almost lean toward making use of a dual citizenship analogy, of determining it as belonging to two literatures, one due to the language and the other due to the theme. (Beker, 1995, 23) When dealing with the Italian minority, similar dilemmas truly do arise, which can then be resolved in accordance with a model suggested by Beker. The situation becomes further complicated because the existence of a literary diaspora also must be taken into account.

The Italians do not devote much attention to these topics. The Apennine Peninsula, encompassed by the Alps, was historically always preoccupied with its own linguistic uncertainties, not leaving much interest for the «outskirts». However, the meeting points of Croatian and Slovenian residents, especially those occurring in Trieste, were afforded attention. The scientist who devoted the most to research of the Italian minority's literature in Istria and Rijeka was the late professor Bruno Maier of the University of Trieste. In his work, Maier claims: The literature of the diaspora, the Italian minority and that of the intellectuals who arrived from Italy after World War II should be viewed as being a part of a collective literary and cultural action, albeit with its own specific and recognizable characteristics. (Maier, 1996, 8) As such, notes Maier, it justifiably also enters the domain of Italian national literature, although contact with foreign literature should be taken into account: This contact most definitely does not possess a negative connotation, it does not represent impoverishment as one might have thought it to in the past, but rather enrichment and a contribution to a mutual Weltliteratur (or world literature) within which each individual literature, including the literature of the Italian minority in Istria and Rijeka, has its definitive place. At this point we can even speak of a mutual European culture. (Maier, 1996, 8)

In terms of defining Istrian literature written in Italian, not all authors are in agreement. As such, in his monograph Venezia Giulia: lineamenti di una storia etnica e culturale (Venezia Giulia: Outline of an Ethnic and Cultural Story) the historian Ernesto Sestan claims that only those authors who were active in Istria throughout the centuries can be considered part of Istrian literature. According to 
Sestan, those who emigrated and contributed to the cultural enrichment of other literatures or Italian regions cannot be considered as part of this literature.

However, Bruno Maier believes that Istrian literature encompasses authors who were born and were active in Istria, authors who were born here but were forced to emigrate and be active elsewhere, and even those authors who weren't born in Istria but who resided here and contributed to the cultural and literary livelihood of Istria. (Maier, 1996, 8)

In between 1919 and 1945, continues Maier, literature from Istria and Rijeka is united and mixed with national literature. However, after 1945, two parallel literatures with clearly defined characteristics are formed: on one hand, the literature of the diaspora, the exodus, and on the other hand the literature of the Italian minority, i.e. the modern Italian literature of Istria and Rijeka. The latter has its own thematic and stylistic specificities: the feeling remains, along with the remnants of Italian national literary tradition, but it is all combined with a novel human and cultural reality. A new literature is formed, with clear specificities and characteristics, if for no other reason that a differing thematic. (Maier, 1996, 10)

According to Bruno Maier's theory, this causes the Italian minority's literature to represent an independent, clearly defined expression of "borderline literature " and become part of the national literary panorama. Criticism has often approached this literature favorably because of its relatively numerous authors and high standard of their works. (Maier, 1996, 116)

Maier emphasizes that the literature of Istria and Rijeka in italian language has, in its own original manner, managed to unite the thematic wholes of the native people with those that the local reality offers. Within this literature, there exist two main directionalities: on one side socialistic realism and on the other individualpsychological thematic. From a linguistic and structural standpoint, this literature presents novel solutions in combination with traditional traits. (Maier, 1996, 123)

What shouldn't be forgotten, claims Bruno Maier, are the certain limitations of this literature which relate to the excessive attention paid to local situations and local folklore, as well as local individual and collective fates. (Maier, 1996, 124) It is somewhat difficult to agree with this claim, more so because the circumstances of Istria, Rijeka and Dalmatia are very much present in the works of even the most famed disapora authors, who have succeeded in presenting imposing themselves to both the Croatian and Italian literary public. This literature's originality, and in a sense its further value lies in that is serves as an expression of a special region where great European civilization overlapped historically. The differences between cities and villages, and linguistic and ethnic specifications are so pronounced and susceptible to change even within the smallest of areas that it is almost inevitable that they produce special works of literature, even today.

Maier is most certainly correct when he emphasizes that a certain balance is present within this literature. The realistic current of the Italian minority's literature, notes the Triestini professor, is characterized by its moderation and its respect for geographical realness and history. (Maier, 1996, 125)

Nonetheless, Bruno Maier overuses the notion of Istrian literature and fails in, or rather refuses to, ultimately define the complicated relationship between the 
literature of the minority and that of the diaspora, or better yet the difference between the literature of those who stayed and those who fled. Those in the latter category seem to be the ones mentioned in everyday speech.

The question that repeatedly imposes itself, emphasizes Ines Srdoč-Konestra, a scientist from Rijeka, is whether literary production, in this case specifically that of Italian authors from Rijeka, is only that which is created in Rijeka (i.e. written by those who stayed) or whether this literary production should be expanded to include literary works created outside Rijeka. In favor of this expansion is the fact that Rijeka often finds itself as the thematic centerpiece of these works, and is often noted as the birthplace and place where one has become enrooted. As such, it becomes the literary topos, the central establishment of authors who have left, claims Ines Srdoč-Konestra.

The matter of those who «fled» and those who «stayed», continues Ines Srdoč-Konestra, is a sore spot which has been passed on from generation to generation for fifty years and is difficult to overcome, so that even younger generations free of actual traumatic events are often swept up in a collective recollection of the exodus. The same claim can be applied to those who stayed, because they, too, often render the traumas of another as a literary theme. Nostalgically rummaging through their own cultural inheritance, they are prone to pasatistic themes, concludes Ines Srdoč-Konestra, specifically analyzing the situation in relation to Rijeka. In that sense, however, there exists no significant difference in relation to the situation on Istria's West coast, stretching from Pula to Umag, where the minority is much less enrooted.

The problem between these two parallel literatures (that of the minority and the diaspora) remains: perhaps it is simply the political inertia of the minority, i.e. the Italians who have remained in Istria and Rijeka, that leads to a lack of political will for embedding the diaspora's literature into the integral modern Italian literature of Rijeka and Istria.

\section{Rectification of the past}

The final years of communism and the Berlin Wall's fall led authors belonging to the Italian minority to reevaluate old truths and abandon their socialist reality. They began to gradually begin critically perceiving the Italian history of Istria and Rijeka following World War II, and to, in a sense, become closer to diaspora related themes. However, there remained pronounced differences between the viewpoints of the minority's cultural activists and those of the diaspora.

Writers who are active in Istria, although to a great degree left-wing oriented, nonetheless love to bring attention to their victorious struggle to preserve the Italian language and identity in Istria and Rijeka in the period after World War II. In accordance, Claudio Ugussi emphasizes that when analyzing the cultural state of the Italian ethnic group within Croatia, one must take into account both political and social features: It is unquestionable that the events immediately occurring after World War II had a crucial role in the cultural development of the Italians that 
remained in Istria, since a significant part of the cultural livelihood that developed within the region and Rijeka from 1945 until today is marked by a firm intention to preserve one's own identity. It is certain that some values, now irreversibly lost, cannot be revived. (Ugussi, 2003, 1)

The rare few who remained - the proletarians (partially due to their ideology, partially due to their belonging to the working class) - continues Ugussi, were faced with a completely novel reality and soon realized that, following this great exodus of sorts, their years were numbered. They realized that some values must nonetheless be preserved and that it was up to them, "the survivors», to eradicate certain attempts, which were at times cleverly concealed, but most often blatantly obvious, to devalue and abolish that which was left of their language and their culture. (Ugussi, 2003, 2)

Those deserving of the credit, remarks Claudio Ugussi, for preserving our ethnic group are undoubtedly the teachers, not only due to their work with children in schools, but also their efforts within the Italian Community. In the meantime, universities in Zagreb and Ljubljana (in the past, these universities did not offer admission to foreign students) welcomed bright new Istrian minds, as well as Italians. Simultaneously, the very first works of literature were born, first through reticent poetry which slowly followed the current of Italian hermetism, but which was nonetheless plot-wise and significance-wise tied to the motherland. (Ugussi, 2003, 2)

Writing in the pathetic tone that dominated the minority's voice throughout the last few decades, Ugussi continues: How could one write and not mention the exile and all the repercussions suffered because of it?! To leave out mention of the empty and torn down houses, the abandoned lands that were now barren, the olive groves that dried out because of neglect and now serve as evidence for a forgotten diligence? How does one not mention the endless pain of a people that were torn from their roots? This was a taboo, one of many within the past regime. It was because of this that we were left with nothing else than the consolation of this hermetic poetry, through which we could express, albeit in a less explicit way, the existential dissatisfaction that consumed us. (Ugussi, 2003, 3) Reading between these lines, we are also afforded with a response to the diaspora's cultural employees who often resent the silence of authors and other representatives of the Italian minority, or rather openly embrace the socialist values present during the existence of ex-Yugoslavia.

After the Berlin Wall's fall, many abandoned their prior convictions and even renounced the poetic works in which they celebrated Tito and Yugoslavian values. The question now presenting itself is how to move forward, since freedom is no solution in itself. Ugussi then proposes a rhetorical question, one not easily answered: Even in today's conditions, living and working within the new environment of a young, democratic and lawful state, and with our motherland's much older democracy, are we safe from all forms of discrimination? Since all our activities in terms of culture are to a great extent dependant on the support of these two nations, we can hope that opportunism and political gameplay are definitely behind us. The very fact that we are not self-sufficient can give way to complexes 
which may cause us to feel like second-class citizens, halt us in our artistic and literary endeavors, as though the existential discord of individuals or entire communities was not enough. Due to a lesson learned long ago, the old generation is already case-hardened with the DNA of survival and just may prosper; we should therefore nurture the young sprouts, allow them to bloom so that they may blossom into something confident that is free to act without restraint within our society. (Ugussi, 2003, 5)

\section{Are we equal?}

The literature of Croatia's Italian minority is poorly received in Italy, save Trieste, since Italy, as we have witnessed, generally finds it difficult to define, let alone valorize peripheral cultures. When viewed through the eyes of distinguished minority authors, how is our reality perceived? Authors of the minority often feel unaccepted or not sufficiently accepted by the culture of the majority. Giacomo Scotti, a prolific writer from Rijeka originally from Naples (one of the intellectuals that set up residence here after World War II and have been the leading voices for the culture and literature of the minority) claims that, even today and despite the demise of an autocratic regime, it is not easy to live within the bounds of a national minority, it is not easy to be a Croatian citizen of Italian extraction. And it is not easy, continues Scotti, to break free from the cultural circle of the minority and integrate oneself into the Croatian intellectual milieu. Italian authors in Croatia, both living and deceased, claims Scotti, were excluded from encyclopedias listing Croatian authors, such as "The Lexicon of Croatian Authors». They are nowhere to be found even within the encyclopedia of foreign authors ("The Lexicon of Foreign Authors»). Simply put, they are treated as undesirable foreign beings. As such, even the most significant of these authors are excluded from elementary and high school reading materials in Croatia. Such a low «cultural» policy definitely does not contribute to the formation of a society in which members of ethnic minorities within Croatia, as well as authors and other intellectuals, can proclaim feeling satisfied and enthusiastic about this country, which serves as their homeland as well. Croatia doesn't know how to offer a warm embrace to its minorities. (Scotti, 2003, 1)

While speaking of the relationship between Rijeka's literature and Italian literature within Italy, Ines Srdoč-Konestra adamantly concludes: Italian critical and literary-historical writings seldom deal the literary production of Italians in Rijeka, and authors from Rijeka who emigrated into Italy and are active there are treated no more favorably. The interest reaches as far as Trieste and the surrounding area, as these areas are also multicultural, but in other parts of Italy, the Italian literary enclave of authors from Rijeka is almost unheard of. Comparison with Croatian literature is present only in circles within Rijeka and Istria. Primarily, this allows for bilingual publications (although most residents of Rijeka are no longer bilingual), monographic editions as well as inclusion in periodic publications. As such, literary criticism can react to new books and be up to date with recent production. Croatian literary history does not keep up with segments of the minority's literature. We can almost conclude that Croatian and Italian literature in 
Rijeka coexist, albeit as two opposing currents that are not expected to meet, as though they do not have the same starting point, each following the growth of its own poetic seed. (Srdoč-Konestra, 2004, 1)

However, it is not all that hopeless. At the end of the 1980's, a new interest for the identity of the city is awoken, including its culture and literary past, a past which undoubtedly encompasses the studying of the Italian entity. Certain significant projects in publishing are founded, which offer positive motivation to a young generation of researchers interested in the literary and cultural history of the city. Croatian researchers began to deal with delving into Rijeka's Italian component, researchers that were in this case members of the majority, states Ines Srdoč-Konestra.

Rijeka's cultural history began to be approached and questioned with a decreasing amount of ideological interference. The city's Italian component was researched by experts in different fields, which gave way to an increasing number of published works dealing with the theme of the city's cultural and literary history, in Croatian. Preexisting tensions in relation to the diaspora are placated, which leads to a cooperation with the Research Society of the History of Rijeka which they founded in Rome, as well as their Archive which possesses documents unavailable in Rijeka. It would seem, concludes Ines Srdoč-Konestra, that narrow-minded national interests, whether of a minority or majority, can be subjugated by a desire for the genuine coexistence of two cultures, when one acknowledges the specificities of the other.

\section{The phenomenon that is Rijeka}

Because of its mixedness, borders, communal autonomy and civilizational relation to more developed regions, the city of Rijeka has created a somewhat unusual cultural substratum, as well a unique profile, claims Tonko Maroević, also noting that although once privileged and overrated and later consciously neglected and repressed, Italian literature within Rijeka does deserve special attention, both as an integral aspect of the local chronicle and as a piece of regional participation in universal, epochally relevant currents. Thanks to its existence, it is possible to speak of that region's cosmopolitan regionalism, one comparable to Santarcangelo's formulation regarding the specific features of Giulio-Venetian authors from the borderlines separating Mitteleuropa and the Mediterranean. When mentioning the literature of Rijeka, it is important to remark on the city's dialect as being comparable to the Istrian-Venetian dialect which is spoken by the Italians autochthonous to Rijeka, the language of choice for written works of the past and one used even today for poetry and prose. The fact that Italian was spoken in many cities along the coast during the last century is a result of the centuries long rule of the Venetian Republic over the entirety of the Eastern Adriatic coast (although never in Rijeka and Trieste), a rule that also dictated the language's spread throughout the Mediterranean. It was the language of the maritime and trade industries, and also served as the sole language of education. The old «lingua franca» deeply rooted itself in certain communities, becoming the language of everyday communication, 
even providing the people with a seal of cultural identity. However, cities continued to live together with their hinterlands: any and all imposition of national categorization when it comes to literature serves to create confusion. Even the very verbalization of this notion creates confusion, states Ines Srdoč-Konestra: Italian literature in Rijeka (this also includes authors whose medium of expression was the Croatian language, but were translated into Italian) or simply the literature of Fiume, or perhaps even Rijeka's Italian literature. In any case, the first variant is what appeals most to the Croatian scientists from Rijeka, while the phrase literature of the Italian minority is much less present, as it acquires a certain national feature which can prove significantly problematic within Rijeka.

Rijeka's reality can be educational, because the national, linguistic and cultural integration that occurred in this city, the largest regional center of the North Adriatic (save Trieste where similar situations have been known to arise), later significantly aided in Istrian literary creation.

\section{The future of the literary minority}

While Croatian literature has been shown to change as new generations are born, the literature of the minority remains stagnant, especially in Rijeka. Ines Srdoč-Konestra notes that generational shifts in Rijeka's Italian literature are not specific, as they don't even exist as such. The most vital segments of Italian literary production in Rijeka since the fifties up until today are comprised of authors who arrived in Rijeka after World War II, driven by the victory of a socialist ideology. Although seemingly odd, Lucifero Martini, Alessandro Damiani and Giacomo Scotti were the ones dominant in marking literary production up until the nineties, when certain autochthonous authors from Rijeka such as Ezio Mestrovich, Nirvana Ferletta and Laura Marchig became relevant. As language serves as the crucial medium of any literary work, the problem with minority literature is that Italian is not sufficiently utilized in communication. Modern literary aspirations, especially those in relation to linguistic experimentation, are difficult to translate into a code that is not sufficiently utilized. This fact contributes to there not being any younger generations arriving after the «old(er)» and «adult» generations that will, emphasizes Ines Srdoč-Konestra, approach »the literary task « in an anticonformist and innovative manner. Giacomo Scotti is adamant in his claims that there will be no more Italian authors present in Rijeka after his death (and Damiani's), because they are not graduating from schools where the curriculum is presented in Italian. The Italian minority's creative culture in Rijeka is in jeopardy. (Scotti, 2003) We have no more musicians or authors and as such Italian culture within Rijeka is clearly doomed for extinction, claims Scotti. However, this claim is only applicable to Rijeka's specific situation, as Italian literature in Istria has somewhat proved its livelihood even within younger generations. 


\section{Istrian Romance tri-lingualism}

The literature of Istria's Italian minority, apart from utilizing the Italian literary language, is also expressed through the Istrian-Venetian dialect (the Istrian variant of the Venetian dialect, a tongue related to the modern Triestini dialect), as well as through the Istriot dialect. In relation to the latter (a dialect which is almost defunct, being present in only six town-enclaves in Southwestern Istria: Rovinj, Bale, Vodnjan, Fažana, Galižana and Sišan), distinguished Croatian linguists feel that it should be classified as a distinct language which should not be entered into the Italian language corpus. Despite these opinions, Istriot literature is de facto classified as being part of Italian minority literature, as speakers of this dialect (one on the border between the Apennine and Balkan Romance languages) historically attended schools in which the curriculum was presented in Italian, and it is used by writers who also use Italian and Istrian-Venetian. A dual and simultaneous presence of both a literary language and local dialect variant is also a characteristic of Croatian literature in Istria: the themes of these two literary groups are very similar. When translated, transference from one dialect to another (for example, from Chakavian to Istrian-Venetian) seems natural and seamless and faithfully depicts the essence of the original.

\section{Literature of the diaspora}

The author that came to be somewhat of a symbol for a plural Istria is Fulvio Tomizza. As he relocated to Trieste, writing his first novels there, Tomizza's work is officially classified as belonging to the literature of the diaspora. However, Trieste, the city in which he resided and wrote for many years, never truly accepted him. In the end, he was wholeheartedly accepted by the general public, including the Istrian public, due to his continual devotion to using the written word and cultural action as means for transfiguring impermeability into pervasion and closeness. In his literary opus, he predominantly speaks of post-war circumstances in Istria and Trieste: we can freely say that amongst other reasons, Tomizza rose to fame because he dealt with the topics that would only much later, at the end of the 1980's, become usual themes within the literature of Croatia's Italian minority, as well as the broader domain of Croatian literary creation. Fulvio Tomizza's literary opus (as well as the opuses of other diaspora authors) is comparable to the works of Croatian authors in Istria and Rijeka, primarily those of Milan Rakovac and Nedeljko Fabria, authors who also touched upon historical themes. It is a paradox of sorts, the difficult to realize aspiration of Italian authors active in Croatia is something that the diaspora's main authors have managed: to create ties to Croatian literature so that it may be accepted by the literary, as well as the general Croatian and Italian public.

Therefore, how can we classify Tomizza as an author from Materada, a village between Umag and Buje, a location straddling the border that divides Croatian and Italian culture? He is not the only problem, there are other writers from the borderlines between civilizations that are perhaps much more similar than one 
would think, if we take the twentieth century's grueling European legacy into account. In reality, Fulvio Tomizza, although too often classified as an Italian author from a Slavic culture, belonged to no one and belonged to everyone, stated Ciril Zlobec.

However, when dealing with the author from Materada (which also served as the title of his first novel), we can speak of a dual affiliation. Although justifiable considered exclusively and Italian author, the Istrian Fulvio Tomizza created a prosaic opus that has significantly touches upon Croatian themes, as Croatia is his homeland... During the eighties, therefore quite late, his works were translated into Croatian, which provided the communist authority with an uneasy autobiographical base for his novels, as well as with the author's devastating recollections of a time when many Italian families were forced to leave their Croatian homeland because of the government's reflexibility. Although the land in which they born had lost its, allegedly, true name for a large number of Italian exiles, the fact remained that these people, especially the authors amongst them, had two homelands and that they were, surprisingly, affiliated with two different literatures, (Prosperov Novak, 2003, 534) writes Slobodan Prosperov Novak.

Tomizza was better prepared than other authors from his region to face the plurality that was present in Istria... Along with Enzo Bettiza of Split who, as well as being one of the most famed Italian journalists, also wittily wrote of his memories growing up in Dalmatia, Fulvio Tomizza is the most significant literary exile, and as such is also part of Croatia's literary history, (Prosperov Novak, 2003, 535) concludes Slobodan Prosperov Novak.

\section{Conclusion}

Throughout their entire history, the Croatian people have built a very specific relationship with those that can be considered their neighbors. Croatia's literary history is in fact a discontinued story about those same neighbors, it is a history within which there exist no authors who would be considered any less Croatian due to the logic of blood and soil or because of their national or international political choices. Croatian literature was founded and conditioned by the variety of it's contributors' political choices and it always was and always will be a unicum of diversity, (Prosperov Novak, 2003, 343) implicitly writes Slobodan Prosperov Novak. The same author goes on to emphasize: The foundations of humanistic education in the Mediterranean and Central Europe were laid by an Istrian Slav, Pier Paolo Vergerio. (Prosperov Novak, 2003, 28)

With that we, in a sense, return to the beginning, because in his writings on literary history, Bruno Maier also named Pier Paolo Vergerio as one of the main authors of Istrian literature and according to him, Italian literature.

If we accept literature as not only being based on the acknowledgment of diversity, but also as a result of that same diversity, the Italian minority's literature, or rather Italian literature from the North Adriatic and even from regions stretching farther South (a definition that doesn't necessarily imply a clear national division or 
affiliation) inevitably becomes a part of general Croatian literature, according to theme, ambient and closeness of dialect. Thus, the question of dual affiliation remains. Authors of this literature wish to be accepted in Croatia, while at the same time aspiring to become part of the broader Italian lingual and cultural domain, in the scope of its intermingling with other cultures. The matter at hand is an intercultural literature, in which the hinterlands become a focal point where literature and affiliation is observed in a truly original manner, where regional specificities dialectically coexist with more traditional national viewpoints. If these specificities are comprehended in a flexible and correct manner, whilst acknowledging national history, both literatures and cultures can serve to be enriched. With that, the question proposed by Miroslav Beker can finally be provided with at least a multifaceted response.

\section{Bibliography}

Maier, B. (1996), La letteratura italiana dell'Istria dalle origini al Novecento, Trieste: Ed. Italo Svevo.

Scotti, G. (2003), La letteratura italiana dell'Istria e di Fiume, Rijeka: La Battana, XL, n. 149/150.

Pužar, A. (1999), Papirnati grad, Rijeka: EDIT — ICR.

Novak, P. S. (2003), Povijest hrvatske kniževnosti, Zagreb: Golden marketing.

Scotti, G. (June 19, 2003), the works read at the round table discussion Položaj talijanske manjine u Hrvatskoj (The Italian Minority's Position in Croatia) which was organized by the Croatian Helsinki Board and the Heinrich Böll Foundation, Zagreb.

Ugussi, C. (June 19, 2003), the works read at the round table discussion Položaj talijanske manjine u Hrvatskoj (The Italian Minority's Position in Croatia) which was organized bythe Croatian Helsinki Board and the Heinrich Böll Foundation, Zagreb.

\section{From the Internet}

Srdoč-Konestra, I. (2004), Riječka književnost na talijanskom jeziku www.matica.hr/Kolo/kolo2004, issue 4. 